\title{
Tackling Inhibitions to Careers in Science and Technology through Differentiated Mentoring Approach
}

\author{
Stella N. Nwosu ${ }^{1}$, Rebecca U. Etiubon ${ }^{2}$ \& Theresa M. Udofia ${ }^{2}$ \\ ${ }^{1}$ Institute of Education, Faculty of Education, University of Uyo, Uyo, Nigeria \\ ${ }^{2}$ Department of Science Education, University of Uyo, Uyo, Nigeria \\ Correspondence: Stella N. Nwosu, Institute of Education, University of Uyo, Uyo, PMB 1017, Akwa Ibom State, \\ Nigeria. Tel: 234-802-957-5272. E-mail: staranyi@yahoo.com
}

Received: April 21, 2014 Accepted: May 30, 2014 Online Published: July 29, 2014

doi:10.5539/ies.v7n8p124 URL: http://dx.doi.org/10.5539/ies.v7n8p124

\begin{abstract}
Encouraging women to go into Science and Technology (S\&T) careers should start with the young girls. In developing countries, such as Nigeria, girls experience challenges in studying science and technological subjects and pursuing careers in these professions. The study identifies factors that inhibit Nigerian girls from undertaking careers in S\&T. A sample of 228 Nigerian Senior Secondary School girls was used for the study. A "Female Students Science and Technology Inhibitions Questionnaire" (FSSTIQ) was used to elicit responses from the girls on conceptual, psychological and physical inhibitions to their studying S\&T subjects. Percentages, mean and standard deviation were used to describe the data obtained. The results reveal that the major conceptual, psychological and physical problems the girls encountered were mathematical concepts, perception of S\&T subjects as being difficult, and inadequate time to study. A "Differentiated Mentoring" approach is recommended for engendering effective mentoring of school girls interested in pursuing science and technology careers.
\end{abstract}

Keywords: science, technology, conceptual inhibitions, psychological inhibitions, physical inhibitions, differentiated mentoring

\section{Introduction}

\subsection{Gender Differences in the Choice of Science and Technology}

For any nation striving for economic development the inclusion of the women folk in all spheres of the economy, including S\&T is an imperative. The average Nigerian school girl may be willing to embrace science and technology subjects, but due to some inhibiting factors, she is not able to pursue these subjects to conclusion. In Nigeria, as is in most nations of the world, gender differences affect choice of discipline. These differences tend to magnify at higher educational levels. Generally, women are overrepresented in education and health, equally represented in the social sciences, business and law; and underrepresented in engineering, manufacturing, construction and sciences (UNICEF, 2008). It is necessary that nations' and concerned groups should attend to these gender-based differences by putting in place strategies to tackle them. The women folk must be fully involved and participate in development in all fields; for the rapid socio-economic development of a nation has been observed to depend on the caliber of women and their education (Schultz, 2002).

Inhibitions to careers in S\&T originate from problems experienced by the girls in pursuing S\&T at the Secondary School level. These may be as a result of conceptual problems of difficulties in understanding the concepts in S\&T subjects. For instance, girls are found to outperform boys in language skills, while boys have a little advantage over girls in Mathematics (UNIGEI, 2008). These differences in performance can eventually result in lower pass rates for girls. This places them at a disadvantage in their meeting the entry requirements for tertiary institutions; this will result in gender imbalance in the students pursuing S\&T disciplines at the tertiary level of education.

\subsection{Inhibitions to the Choice of Science and Technology among School Girls}

Psychological factor such as girls' perception of the subject area, parental and societal attitudes to girls pursuing S\&T disciplines can also inhibit their progress in S\&T subjects. Low female enrolment in Science and Technology in Nigerian higher institutions of learning has been attributed to stereotyping, "girls have been brain 
washed into believing that they are not good in science" (Ker, Ekoja, \& Anejo, 2010, p. 77). Poverty and cultural practices such as early marriage, parental and societal perceptions of the roles of women are predominant in Nigeria as in most of Sub-Saharan Africa. These may emerge as inhibitions to girls pursuing and staying in S\&T careers.

Physical factors, that is, factors that have to do with human activities may also contribute to girls' inability to cope with the demands of S\&T disciplines. These factors include; the school/teachers' ability to provide effective instructional delivery and the girls' roles in the home. These factors have been known to be sources of inhibition to school girls pursuing S\&T careers (World Bank, 2010). In rural Nigeria, girls bear the heaviest burden of house hold responsibilities such as caring for sick parents and the younger siblings (Randell \& Gergel, 2010).

\subsection{Mentoring Girls in Science and Technology}

Mentoring has always been an effective strategy for encouraging young people into better educational aspirations (Watson, 2010). According to Eric Parsole of the Oxford School of Coaching \& Mentoring "mentoring is to support and encourage people to manage their own learning in order that they maximize their potentials, develop their skills, improve their performance and become the person they want to be (MentorSET, 2008). The mentor provides wisdom, guidance and counseling as mentees advance their lives, careers or education. For instance, girls taught Mathematics and sciences by a female teacher are likely to emulate their teacher and are more apt to do well (Packard, 2003). "Exposing girls to female role models in positions of leadership and power that contradicts stereotypes of women role can reduce the generational transmission of gender norms"(World Bank, 2012, p. 59). A mentor guides the mentee to overcome their challenges and find the right direction. Mentoring can be formalized into a regular organized activity targeted to meet the needs of a certain groups.

Differentiated mentoring is derived from differentiated instruction, which is an instructional concept that maximizes learning for all students regardless of their skill level or background. It is based on the fact that there are individual differences in abilities, learning styles and personalities among students in a typical classroom. "Differentiation stems from beliefs about differences among learners, how they learn, their learning preferences and individual interests" (Anderson, 2007, p. 50). When a teacher differentiates instruction, he or she uses the best teaching practices and strategies to create different pathways that respond to the needs of diverse learners. This strategy which has proved to have a positive influence on students' academic performance (Ezekoka, 2004; Ferrier, 2013) can also be adopted to improve mentoring efforts.

There is a gender disparity in the choice of professions across the globe. These differences in the choice of fields of study are more pronounced in Sub Saharan African countries (World Bank, 2010). This includes countries such as Nigeria. Boys are usually free to choose subjects or careers in fields of their interest. They are even expected to choose from science and technology fields. However, among girls there are some inhibitions. These inhibitions are normally in the form of cognitive questions such as: are they intelligent enough to understand Science and Technology concepts; what about their domestic duties as girls and later as mothers; are they physically capable to embark on some of these so-called "masculine" professions? These factors hinder many Nigerian girls from pursuing Science and Technology courses of their desire. Mentoring young girls can be an effective strategy in encouraging them to pursue such careers. The question then is; how can we improve on the mentoring exercise? Effective mentoring should be a holistic exercise that meets the girls' needs. This study identifies inhibitions to studying S\&T subjects among Nigerian girls and, hence, mentoring needs. A mentoring framework is proposed in the study for meeting these needs.

\subsection{Purpose of the Study}

The study aimed at determining the major inhibiting factors to careers in S\&T among Nigerian Girls. Specifically the objectives were:

1) To identify conceptual, psychological and physical problems encountered by Nigerian girls pursuing Science and Technology subjects.

2) To identify the major inhibiting factors to girls pursuing Science and Technology careers in Nigeria.

3) To suggest a framework for mentoring the differentiated needs of the Nigerian girl in pursuing Science and Technology careers.

\subsection{Research Questions}

The following research questions were formulated to guide the study.

1) What are the conceptual, psychological and physical problems Nigerian girls encounter in studying science and technology subjects? 
2) What is the major inhibiting factor to Nigerian girls pursuing Science and Technology careers?

\section{Method}

\subsection{Study Area}

The study was carried out in Akwa Ibom State of Nigeria. The State is in Niger Delta region of the country. The major means of live hood of the Niger Delta people are fishing, farming and trading. Akwa Ibom State is divided into three Senatorial Districts and has thirty one Local Government Areas.

\subsection{Population and Design}

The state has two hundred and forty eight (248) public secondary schools with an estimated population of seven thousand, five hundred $(7,500)$ school girls in both rural and urban areas of the State. The ex post facto research design was used for the study.

\subsection{The Subjects}

The students who participated in the study were Senior Secondary School girls between the ages of 14 to 18 , in years one to three (SSI, SSII and SSIII) representing $7^{\text {th }}$ to $9^{\text {th }}$ grades. The girls in SSI study all the subjects-science/technology and arts. However, the girls in SSII and SSIII are studying science/technology or arts. A sample size of 288 of these Nigerian secondary school girls in Akwa Ibom State, Nigeria, participated in the study. The sample was selected through multistage stratified random sampling. The State is politically stratified into three senatorial districts. Within each senatorial district four schools were selected from a sampling frame of a list of schools in the various Local Government Areas that make up each senatorial district (twelve schools). Two schools were selected from the rural areas and two from the urban areas (including technical schools) in each of the Local Government Areas. Twenty four (24) girls were then selected by simple random sampling using the class lists from each of the twelve schools (8 students each from Senior Secondary I, II and III). A sample of 288 secondary school girls was selected through this process. The girls responded to items on the possible cognitive, psychological and physical problems they encounter in studying science and technology subjects.

\subsection{Instrumentation}

A "Female Science Students and Technology Inhibition Questionnaire" (FSSTIQ) were used for the study. The instrument is a 15 item rating scale consisting of three sections; section 1 elicited demographic information from the girls on their year of study. Section 2 elicited information from the respondents on conceptual problems, which, in the study implies the girls' perceived difficulty in understanding concepts in science and technology subjects. The section required the girls to indicate their level of agreement or disagreement on difficult nature of science and technology subject concepts on a 4 point scale of, 4 strongly agree; 3 agree; 2 disagree and 1 strongly disagree. Section 3 measured psychological and physical problems the girls experienced in studying science/technology. The psychological (affective) problems items are: their perception of boys being better in science/technology and science/technology being difficult, and also their parents and community's support of their doing science or technology. The physical (psychomotor) problems include activities of the girls or others that can hinder their studying science and technology subjects. These include: domestic chores; activities of the teacher/school; time constraints and poor manipulative skills. The respondents were required to indicate on a four point scale the level of their agreement or disagreement with the declarative statements on possible psychological (four items) and physical (five items) problems. The use of these factors in the study is based on various research findings (UNIGEL, 2008; World Bank, 2010; Ker et al., 2010; Randell et al., 2010; David, 2011) identifying these factors, among others as the factors that prevent girls from studying Science, Technology and Mathematics (STM). The inhibiting factors, in this study, have been categorized into constructs; cognitive, psychological (affective) and physical (psychomotor) inhibitions. This mode of categorization is adopted from Bloom's taxonomy of educational objectives; into Cognitive, Affective and Psychomotor each dealing with knowledge, emotions and physical activity respectively (Randall, 1994).

The validity of the instrument items was established by three faculty members who posses expertise in science education and gender studies. The instrument was subjected to a test of reliability using the Cronbach's Alpha test of internal consistency. A reliability estimate of .81 was obtained for the instrument.

\subsection{Data Analysis}

Data collected using the instruments was collated and analyzed using percentages, mean scores and standard deviation. To answer research question one, the students' responses to the items on difficulty of science and technology concepts were organized into two categories of "agree" (indicating that the subjects were difficult) 
and "disagree" (indicating that the subjects were not difficult). The responses to the items on psychological and physical problems were organized into similar categories implying "a problem" (agree) or "not a problem" (disagree) to their studying science and technology subjects. The frequency distribution and percentages of the respondents' responses to each category was determined. The mean scores of the responses to each of the variables (conceptual, psychological and physical) were also computed. A decision rule of a mean score of 2.50 and above indicating "difficult " or "a problem" for the conceptual, psychological and physical variables, while a mean of 2.49 and below as indicating "not difficult" or "not a problem" for the conceptual, psychological and physical variables was used to rank the responses. The frequency distribution, percentages, and mean scores of the responses to these items were also used to determine the overall responses to conceptual, psychological and physical variables and thus the major inhibiting factor.

\section{Results}

\subsection{Research Question 1}

\subsubsection{Conceptual Problems}

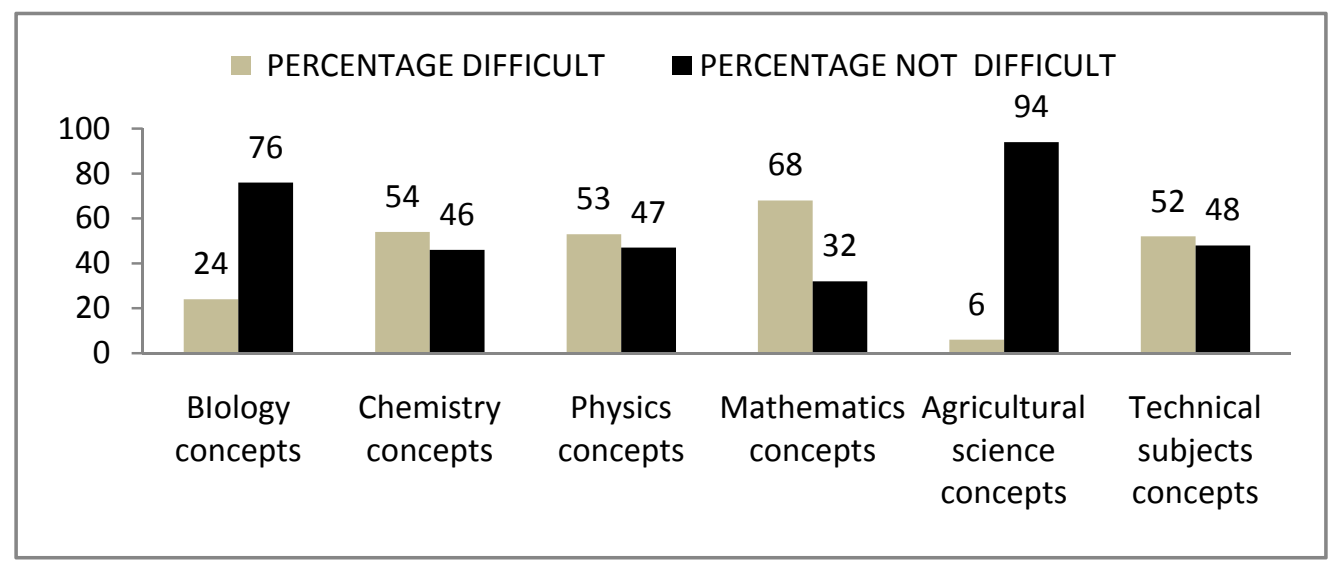

Figure 1. Percentages of the girls' responses to difficulty of science and technology subjects

Figure 1 presents the results of the frequency distribution, percentages of the students' responses to the level of difficulty of science and technology subjects' concepts. The results reveal that the respondents indicated the Mathematics concepts as the most difficult (68\%) followed by Chemistry (54\%) and Physics (53\%). Agricultural Science was found the least difficult $(6 \%)$.

Table 1. Mean scores and standard of responses to difficulty of science and technology concepts $(\mathrm{N}=288)$

\begin{tabular}{lcc}
\hline Difficult Subject Concepts & Mean & SD \\
\hline Biology concepts & 1.98 & 0.991 \\
Chemistry concepts & 2.57 & 1.117 \\
Physics concepts & 2.56 & 1.118 \\
Mathematics concepts & 2.86 & 1.061 \\
Agric. Science concepts & 1.62 & 0.689 \\
Technical Subjects concepts & 2.54 & 1.119 \\
\hline
\end{tabular}

Table 1 presents the results of the means and standard deviation of the responses to the level of difficulty of science and technology subjects' concepts. The respondents also rated mathematics (Mean 2.86, SD 1.061) as the most difficult. And Agricultural Science as the least difficult (Mean 1.62, SD 0.68). These results generally show that these students are poor in Mathematics and they could as a consequence find science subjects difficult. 


\subsubsection{Psychological Problems}

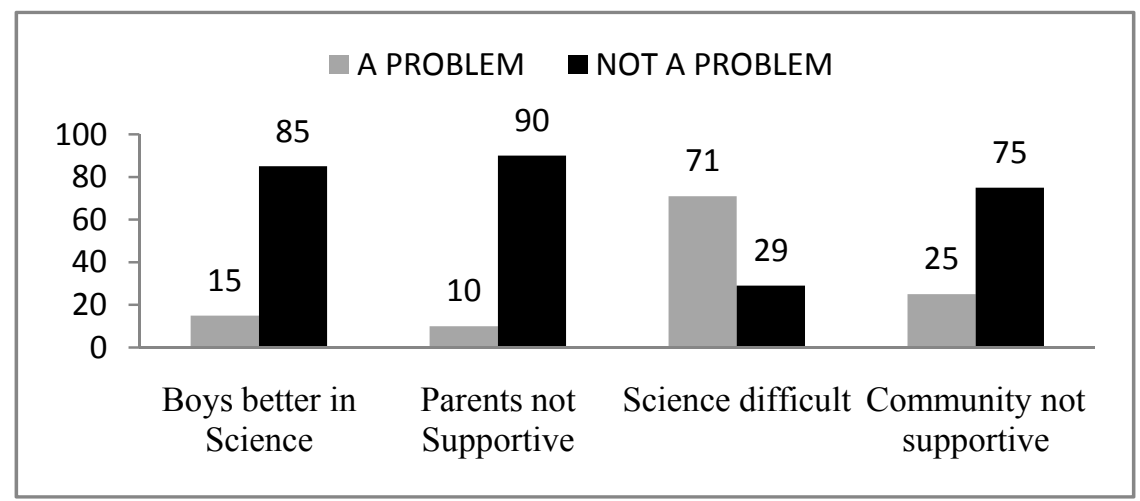

Figure 2. Percentages of students' responses to psychological problems

Figure 2 presents in percentages the students' responses to the items on the psychological problems the girls encounter in studying science and technology subjects. These results show that the greatest psychological problem is the girls' perception of science subjects being difficult (71\%).

Table 2. Mean scores and standards of responses to psychological problems $(\mathrm{N}=288)$

\begin{tabular}{lll}
\hline Psychological Items & Mean & SD \\
\hline Boys do better in science subjects & 1.80 & 0.871 \\
I am studying science subjects against my parents wishes & 1.72 & 0.806 \\
Science/Technology is more difficult than Arts subjects & 2.92 & 1.039 \\
My community frowns at girls engaging in science and technology subjects & 1.86 & 0.916 \\
\hline
\end{tabular}

Table 2 presents the mean scores and standard deviations the girls' responses to the items on the psychological problems the girls encounter in studying science and technology subjects. 'Perception of science subjects being difficult is rated as the only psychological inhibition (mean 2.92, SD 1.039) the girls' experience. Although, their parents are not a hindrance to their studying science and technology subjects (mean 1.72, SD 0.806) the girls themselves perceive the subjects as difficult.

\subsubsection{Physical Problems}

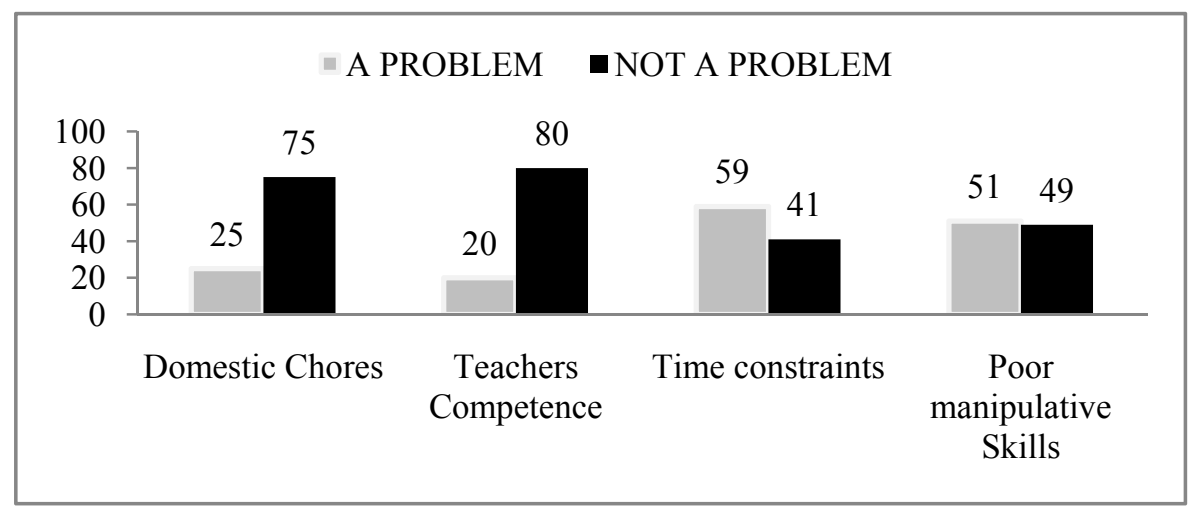

Figure 3. Percentages of students' responses to physical problems 
Figure 3 presents graphically, the percentages of the students' responses to the physical problems the girls encounter in studying science and technology subjects. The results reveal that the greatest physical problem the girls experienced in studying these subjects is time constraints $(59 \%)$ followed by poor manipulative skills $(51 \%)$.

Table 3. Mean scores and standard deviation of responses to physical problems $(\mathrm{N}=288)$

\begin{tabular}{lll}
\hline Physical Problems & Mean & SD \\
\hline My duties in the home won't allow me to do science/technology subjects. & 1.86 & 0.916 \\
I don't like how Sciences/technology subjects are being handled in my school & 1.90 & 0.946 \\
I don't have enough time to study science/ technology subjects & 2.68 & 1.105 \\
I am not good at manipulating the equipment in the lab./ workshop & 2.52 & 1.119 \\
\hline
\end{tabular}

Presented in table 3 are the mean scores and standard deviations of the students' responses to the physical problems the girls encountered in studying science and technology subjects. The respondent rating also confirms time constraints (mean 2.68, SD 1.105) as the major physical inhibition after which are manipulative skills (mean 2.52, SD 1.119). These results imply that these girls feel they need more time to study science subjects.

\subsection{Research Question 2}

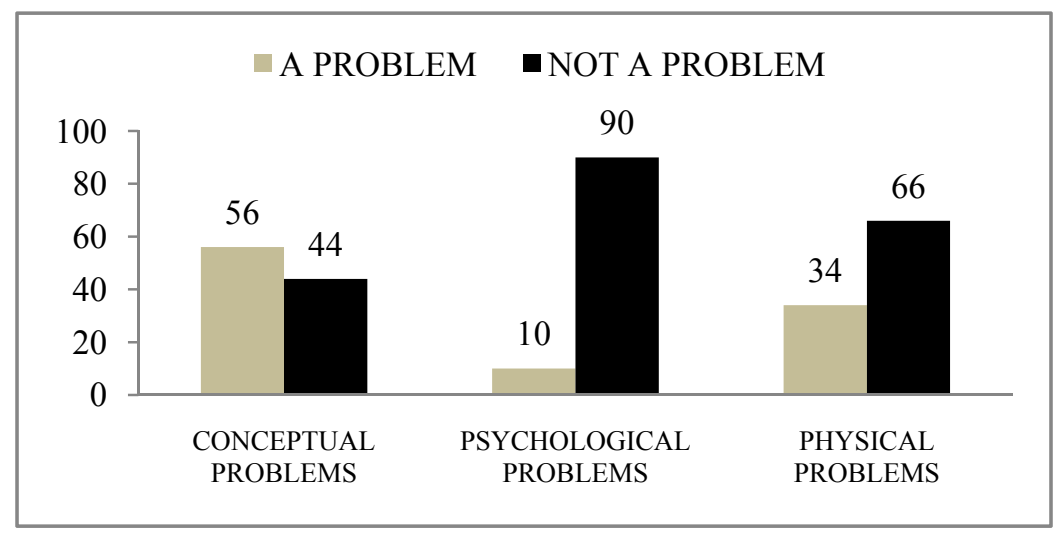

Figure 4. Percentages of overall response to conceptual, psychological and physical inhibitions

In Figure 4 overall responses to the conceptual, psychological and physical problems the girls encounter in studying science and technology subjects are presented in percentages. It shows that (56\%) conceptual problems is the major inhibiting factor.

Table 4. Mean score and standard deviation of overall responses to conceptual, psychological and physical inhibitions $(\mathrm{N}=288)$

\begin{tabular}{lcc}
\hline Variables & Mean & SD \\
\hline Conceptual & 2.355 & 1.015 \\
Psychological & 2.075 & 0.712 \\
Physical & 2.240 & 0.8154 \\
\hline
\end{tabular}

Table 4 presents the mean scores and standard deviations of the overall responses to the conceptual, psychological and physical problems the girls encounter in studying science and technology subjects. The conceptual problems has the highest mean score (Mean 2.355, SD 1.015) and is thus the major inhibiting factor to studying science and technology subjects among these girls. 


\section{Discussion}

Conceptually the girls indicated that they were poor in Mathematics as they found it difficult. This has been found to be generally the case with most students in Nigeria. However, the subjects that do not require much calculation are not difficult for them. They will need to develop their mathematical skills.

Psychologically the girls feel that science subjects are more difficult than the Arts subjects although they don't feel that boys are better in S\&T subjects. These perceptions could result in some of them dropping out in the future, unless there is some kind of intervention to improve their attitudes towards these subjects.

The girls also feel that they do not have enough time to study S\&T subjects. Their perception of S\&T subjects being difficult could have resulted in their desire for more time to study these subjects. Manipulative skills are essential for good performance in S\&T classes. These girls indicated that they are not good in practical classes. This can, to some extent explain the high rating for Chemistry as a difficult subject. The subject, at the secondary school level involves a lot of practical work which are highly manipulative, involving the use of delicate instruments. The respondents have rated conceptual problems, which have been shown to be predominately Mathematics concepts as the major inhibition to studying S\&T subjects. This agrees with David (2011, p. 15) who identified "lack of Mathematics knowledge" as the main obstacle to women involvement in science and technology at higher levels. And with the Secondary School Certificate Examination (SSCE) results in Nigeria where a lot of students perform poorly in Mathematics. The requirements in Nigeria for any candidate to pursue a career in S\&T discipline is a credit pass in Mathematics. Many students in Nigeria are not able to make this result in the SSCE (Punch Newspaper, 2012).

These girls have indicated a variety of areas in which they have problems in pursuing S\&T subjects. However, these inhibitions may be specific to this group. This may or may not be the case for any other group of girls in Sub- Saharan Africa. Different groups may have different inhibiting factors. Identifying these problems and tailoring mentoring activities to tackle the inhibitions specific to a group constitutes "Differentiated" mentoring. "Differentiation is not a strategy, but rather a commitment to a philosophy that will motivate students by meeting them where they are and getting them to where they need to go" (Tillman, 2003, p. 1).

\section{Implications and Recommendation}

The findings imply that the girls require mentoring in the form of strategies to help them improve on their understanding of concepts that are difficult for them in Science and Technology such as Mathematics and counseling for attitudinal change and to cope with studies and time demands. A Differentiated mentoring framework is recommended to engender effective mentoring of female science students. It involves holistic mentoring that attempts to take care of the various identified problems the students experience in pursuing Science and Technology careers. The process is modeled below. 


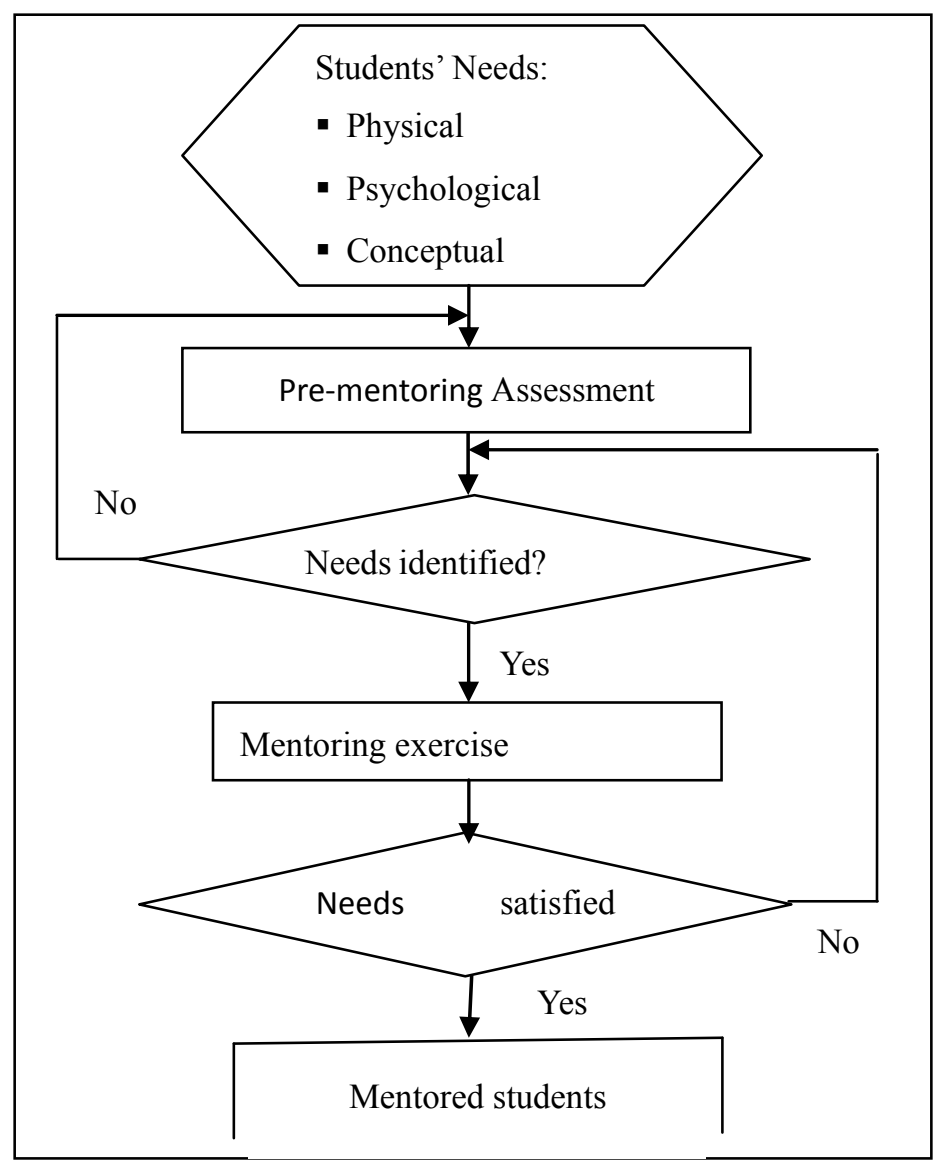

Figure 5. Model of a differentiated mentoring framework

The framework consists of identifying the students' problems in pursing S\&T by taking a survey prior to the mentoring exercise. The information from the students can be used to define the mentoring activities that can help tackle these inhibitions. Feedback is in the form of a post mentoring evaluation form. The process can be repeated at any stage if the need arises.

\section{Conclusion}

Nigerian girls are inhibited from pursuing careers in S\&T due to problems with Mathematics concepts, their perception of science being difficult, inadequate time for studies and poor manipulative skills. Like these girls other girls from different socio-cultural groups all over Africa and beyond will have specific problems that inhibit them from pursuing careers in S\&T. Identifying the specific problems of a group and tailoring mentoring activities towards tackling these problems through Differentiated Mentoring should be among the best mentoring practice for retaining young girls in S\&T careers.

\section{References}

Anderson, K. M. (2007). Differentiating instruction to include all students. Preventing School Failure, 151(2), 50.

David, H. (2011). Overcoming the gender gap in Maths, science and technology: A $21^{\text {st }}$ century view. Journal of Educational and Social Research, 1(3), 15.

Ezekoka, G. (2004). The effects of learning styles on the academic performance of senior secondary Biology students (Unpublished doctoral dissertation). University of Port Harcourt, Port Harcourt, Nigeria.

Ferrier, A. M. (2013). The effects of differentiating instruction an academic achievement in a second-grade science classroom. Retrieved from http//udini.proquest.com/view/the effects-of-defferentiated-goid

Ker, B. O., Ekoja, O. C., \& Anejo, E. E. (2010). Trends in girl-child education in Africa. In C. Ikekeonwu (Ed.), Girl-Child Education in Africa. Enugu: CIDJP press. 
MentorSET. (2008). What is mentoring? Retrieved from http//www.mentorset.org.uk/pages/mentoring.htm

Packard, B. W. (2003). Web-based Mentoring: Challenging traditional models to increase Women's Access. Retrieved from http://ehrweb.aaas.org/sciMentoring/Mentor_Definitions_Packard.pdf

Punch Newspaper. (2012, August 14). 38.81\% candidates' record credit pass in English and Maths in West African Council Secondary School Certificate Exams.

Randall, V. R. (1994). Learning domains or Bloom's Taxomomy. Retrieved from $\mathrm{http}: / /$ academic.udayton.edu/health/syllabi/health/unit01/lesson01b.htm

Randell, S. K., \& Fish, J. (2010). Promoting the retention of women faculty and students in higher education: The Rawandan case. In C. Ikekeonwu (Ed.), Girl-Child Education in Africa. CIDJP press, Enugu.

Randell, S. K., \& Gergel, D. R. (2010). The Education of Girls in Africa. In C. Ikekeonwu (Ed.), Girl-Child Education in Africa. CIDJP press, Enugu.

Schultz, T. P. (2002). Why governments should invest more to educate girls. World Development, 30(2).

Tillman, M. (2003). Differentiated instruction: An overview. Retrieved from http://www.scricboos.org/Goals2001

UNGEI. (2008). Transforming policy and practice for gender in education: A gender review of the 2009 EFA Global Monitoring Report. UNICEF, New York.

Watson, M. (2010). The importance of mentoring young people. Retrieved from http://www.nbpts.org/userfiles/file/TheImportanceofMentoringYoungPeople.pdf

World Bank. (2010). Gender disparities in Africa's labor market. Retrieved from http//openknowledge.worldbank

World Bank. (2012). Gender equality and development. UN World Development Report. Washington D.C. Retrieved from (httpInfoFiles)/E90770090127BDFDC12579250058F520/\%24 http://www.unrisd.org/80256B42004CCC77/

\section{Appendix}

Science Students' Mentoring Needs Assessment Questionnaire

Dear students this questionnaire is for a research study on the problems girls may have in studying science and technology subjects. Please respond to the statements truthfully your responses will be held confidential.

Section 1

Please tick the box which applies to you.

Class: SS $\square$ SSII $\square \quad$ SSIII

Section 2

Please tick the box which corresponds most to your feeling of how difficult the subjects below are for you.

\begin{tabular}{|l|l|l|l|l|l|}
\hline SN & Subject & $\begin{array}{l}\text { Strongly } \\
\text { Agree }\end{array}$ & Agree & Disagree & $\begin{array}{l}\text { Strongly } \\
\text { Disagree }\end{array}$ \\
\hline Difficult Subject Concepts & & & & \\
\hline 1 & Topics in Biology & & & & \\
\hline 2 & Chemistry topics & & & & \\
\hline 3 & Physics topics & & & & \\
\hline 4 & Mathematics topics & & & & \\
\hline 5 & $\begin{array}{l}\text { Topics in Agricultural } \\
\text { Science }\end{array}$ & & & & \\
\hline 6 & Technology topics & & & & \\
\hline
\end{tabular}




\section{Section 3}

Please tick the boxes which most agrees with your responses to the statements below.

\begin{tabular}{|c|c|c|c|c|c|}
\hline SN & Statement & $\begin{array}{l}\text { Strongly } \\
\text { Agree }\end{array}$ & Agree & Disagree & $\begin{array}{l}\text { Strongly } \\
\text { Disagree }\end{array}$ \\
\hline \multicolumn{6}{|c|}{ Psychological Challenges } \\
\hline & Psychological Items & & & & \\
\hline 1 & $\begin{array}{l}\text { Boys do better in science } \\
\text { subjects }\end{array}$ & & & & \\
\hline 2 & $\begin{array}{l}\text { I am studying science } \\
\text { subjects against my parents } \\
\text { wishes. }\end{array}$ & & & & \\
\hline 3 & $\begin{array}{l}\text { Science/Technology } 1 \text { is more } \\
\text { difficult than Arts subjects }\end{array}$ & & & & \\
\hline 4 & $\begin{array}{l}\text { My community frowns at } \\
\text { girls engaging in science and } \\
\text { technology subjects }\end{array}$ & & & & \\
\hline \multicolumn{6}{|c|}{ Physical Challenges } \\
\hline 5 & $\begin{array}{l}\text { My duties in the home won't } \\
\text { allow me to do } \\
\text { science/technology subjects. }\end{array}$ & & & & \\
\hline 6 & $\begin{array}{l}\text { I don't like how } \\
\text { Sciences/technology subjects } \\
\text { are being handled in my } \\
\text { school }\end{array}$ & & & & \\
\hline 7 & $\begin{array}{l}\text { I don't have enough time to } \\
\text { study science/ technology } \\
\text { subjects }\end{array}$ & & & & \\
\hline 8 & $\begin{array}{l}\text { I am not good at manipulating } \\
\text { the equipment in the lab./ } \\
\text { workshop }\end{array}$ & & & & \\
\hline 9 & $\begin{array}{l}\text { Science /technology subjects } \\
\text { are too physically challenging } \\
\text { for the girls. }\end{array}$ & & & & \\
\hline
\end{tabular}

\section{Copyrights}

Copyright for this article is retained by the author(s), with first publication rights granted to the journal.

This is an open-access article distributed under the terms and conditions of the Creative Commons Attribution license (http://creativecommons.org/licenses/by/3.0/). 